\title{
The Use of Peat Deposits of the Russian Federation for Organic Fertilizers Production
}

\author{
Oleg Misnikov, ${ }^{1, *}$ \\ ${ }^{1}$ Tver State Technical University, A. Nikitin Street, 22, 170026, Tver, Russia
}

\begin{abstract}
In agricultural production, soil fertility and the overall productivity of arable land depends on the quality and quantity of mineral and organic fertilizers. The decrease in the humus content in soil observed over the past decade requires a systematic use of various organic fertilizers. The use of peat-based fertilizers guarantees high and sustainable crop yields. Restoration of soil fertility should be carried out by organic fertilizers enriched with humic acids with physiologically active groups, free nitrogen-containing components, a complex of nutrients and micro elements. The author considers the possibility of using humus peat ameliorants for the restoration of disturbed lands and the increase of soil fertility. The production and use of peat-based organic fertilizers and ameliorants in various sectors of the economy is an incentive for the stable functioning of the peat business and a significant factor in the socioeconomic development of the regions of the Russian Federation.
\end{abstract}

\section{Introduction}

In the middle of the last century Russia (the USSR) set a new goal - a sharp increase in the productivity in agricultural production. The main stake was made on the chemicalization, which implies application of mineral fertilizers in crop production. However, the widespread use of different types of chemicals also plays a negative role. As experience shows, the systematic use of solely mineral fertilizers does not increase, but on the contrary, reduces the level of soil fertility, worsens its structure and leads to general degradation [1, 2]. A positive effect occurs with the simultaneous use of both organic and mineral fertilizers.

For example, in the Tver Region (a typical representative of the non-chernozem zone of the Russian Federation), the use of fertilizers steadily increased until 1986-1992. During this period, $120-151 \mathrm{~kg}$ of mineral and 5-7 tonnes of organic fertilizers were applied annually to each hectare of arable land. The average yield of grain crops by this period was $15.4 \mathrm{c} / \mathrm{ha}$, including $22 \mathrm{c} / \mathrm{ha}$ for winter wheat, $20.8 \mathrm{c} / \mathrm{ha}$ for barley, $17.7 \mathrm{c} / \mathrm{ha}$ for rye (in contrast to $7 \mathrm{c} /$ ha in 1960s). Gross grain harvest for the year was on average 890-910 thousand tons $[3,4]$.

It is known that the yield and quality of agricultural crops are directly related to the fertility of soil, primarily characterized by the content of humus [5]. This is evidenced by the practice and results of many years of research by domestic and foreign scientists $[6,7]$.

\footnotetext{
* Correspondent author: oleg.misnikov@gmail.com
} 
Starting in 1992, works on improving land fertility in Russia began to decline at a catastrophic rate, and by 1996-1998 they were virtually shut down [8]. For example, in the Tver region the volume of liming of acid soils has decreased by 50 times by 2003 and made up only 0,5 thousand hectares. Since 2007 it has been completely stopped. Application of mineral fertilizers decreased by 20 times, i.e. to $6.5 \mathrm{~kg} /$ ha of arable area, and application of organic fertilizers decreased by 15 times ( 0.4 tons per hectare of arable land). Cereal yield was $8.4 \mathrm{~kg} / \mathrm{ha}$ of arable area, and gross yield was 120 thousand tons, which is six times less than in the 1990s.

The critical state of the nutrients supply of the soil is evidenced by the calculation of its balance, which has been constantly decreasing over the past 10 years. Currently, it is 35.3 $\mathrm{kg} / \mathrm{ha}$ : including $20.8 \mathrm{~kg} / \mathrm{ha}$ of nitrogen, $2 \mathrm{~kg} / \mathrm{ha}$ of phosphorus and $12.5 \mathrm{~kg} / \mathrm{ha}$ of potassium [4]. Due to the negative balance of nutrients, the formation of crop yields is mainly due to soil fertility. Thus there is a constant depletion of soil.

In production conditions, it is important to determine the level of soil nutrition on the basis of the results of agrochemical survey and select a cheaper range of fertilizers that will ensure the highest return on production investments [9].

It has been theoretically and experimentally established that with increasing the amount of humus, crop growth increases, as well as its yields and quality. For example, there is a high correlation between humus content in soil and gluten content in grain [10]. For example, when the humus content of soil changes from 2.5 to $7 \%$, the gluten content of grain increases approximately twice.

Today, in many regions of Russia there is a negative balance of humus, which undermines the fundamentals of fertility. At the same time, it is necessary to apply at least 13 tons of organic fertilizers per 1 hectare of soil on cultivated areas annually only to compensate for the removal of humus together with the harvest. However, the current situation is such that in most areas of the central non-chernozem area, the saturation of 1 hectare of arable land with organic fertilizers (mainly manure compost) does not exceed 1-2 $\mathrm{t} / \mathrm{ha}$, with the necessary at least 5-6 t/ha. It is practically impossible to reach the specified level of humus application in the area of sod-podzolic soils without the use of other organic fertilizers [11].

The expert community has no doubt that the production and application of peat fertilizers create the prerequisites for high and sustainable crop yields [12]. Peat fertilizers are one of the effective means to increase soil fertility and restore its biological, chemical and physical properties [13]. The nutrients they contain create favorable conditions for normal plant growth and development. Long-term studies have proved that when applying concentrated organic peat fertilizers, crop yields increase from 37 to $73 \%$, i.e. by $50 \%$ on average [14].

Due to Russia's enormous reserves of peat (the reserves of this useful renewable resource are estimated at 150-170 billion tons) and centuries-old traditions of its use, it is an ideal place for the production of such products. Peat should play a significant role in the development of the country's economy, as it has significant potential. Extremely difficult financial situation of agricultural producers in Russia, high cost of mineral fertilizers, reduction of cattle population does not allow increase of the use of traditional organic and mineral fertilizers in the coming years.

Under these conditions, it is necessary to use relatively accessible sources of nutrient replenishment, such as organic fertilizers produced from peat (various types of compost, ameliorants, humates, etc.). They make it possible to activate hard-to-solve forms of nutrients and thus to obtain sufficiently high yields of all crops.

The changed economic situation calls for the development of a different strategy and tactical approaches to provide fertilizers for agricultural enterprises. It is primarily necessary to refocus on local agrochemical resources, because the high price of mineral 
fertilizers, the cost of their transportation, as well as decrease in supplies to the domestic market lead to a serious decrease in their application.

\section{Review}

The technology of preparation and application of organic fertilizers helps to solve several environmental problems simultaneously: waste utilization, improvement of sanitary conditions on the territory of and near large agricultural enterprises (first of all, livestock farms), reduction of gaseous nitrogen losses, obtaining the most part of organomineral fertilizers, bypassing the stage of preliminary preparation. Use of organomineral fertilizers allows reduction of application doses by several times compared to the traditional organic fertilizers. This will significantly reduce costs, provided that the effect on crop productivity is equal (in some cases greater).

The use of mineral fertilizers is aimed at correcting the indicators of effective soil fertility. Chemical meliorants are characterized by the impact on the soil absorption complex. In organic fertilizers the organic component is the basis for the formation of humus, but the concentration of nutrients in them is usually much less. Therefore, traditionally applied mineral fertilizers have a one-way impact on soil fertility and do not create the basis for the formation of humus.

Organic (or organomineral) fertilizers enriched with humic acids with physiologically active groups and free nitrogen-containing components are needed to accelerate the restoration of soil activity. In this regard, a special role is given to the preliminary composting process. Composting is a biochemical process that allows, under conditions of sufficient aeration and humidity, the return of biogenic organic waste and materials to the natural cycle.

The essence of the composting method is as follows. Farm animal waste is mixed with carbon-containing materials, which absorb the liquid component of animal waste and gaseous decomposition products. The mixture is then subjected to controlled biochemical process over a period of time due to microbial activity in the composted organic matter.

The composting process can be broken down into distinctly different stages of stabilization and maturation in terms of physical characteristics. At the stabilisation stage, the temperature rises to the level where thermophilic microorganisms begin to multiply. As the temperature rises, the bacterial population continues to grow due to the consumption of organic matter. The surplus energy released contributes to the rapid rise in temperature. This temperature can be in the range of $55-70^{\circ} \mathrm{C}$ depending on the composting method. At these temperatures, pathogens die, or their numbers are significantly reduced. If the temperature drops, the maturation of the compost can continue. During this period, the organic matter decomposes slowly until it reaches a state of equilibrium. The end product is a mixture of stable components. The end of the composting process is determined by a noticeable reduction in the temperature and the speed of decomposition of solid organic matter. In some cases, the amount of solid organic matter can be reduced by up to $50 \%$ during composting.

The main objectives of composting are to stabilise organic substances susceptible to rotting, preserve nutrients and produce a homogeneous bulk product suitable for use as a structure-forming fertilizer. The composting also "cleans" the product from pathogenic microflora and weed seeds. Properly prepared compost is therefore of double value compared to manure and has a higher degree of nutritiousness and ecological purity.

The frequency of applying organomineral is much lower than that of mineral fertilizers once in 3-5 years fertilizers due to their prolonged action. In addition, they can be applied to the soil in a single run of special technology, together with organic and mineral 
fertilizers, microelements, as well as other necessary plant components (e.g. growth stimulants).

The conversion of peat into high-value organic fertilizer after composting it with lime is confirmed by field experiments with potatoes. The potato yield added $47 \mathrm{c} / \mathrm{ha}$ with the use of the compost, whereas the use of peat only added in the same dose yielded only $19 \mathrm{c} / \mathrm{ha}$ more than under controlled conditions.

Application of humic acid salts of peat - humates - is possible on all types of soils and for all plant species [15]. Annual plants react more strongly to the application of humate at the beginning of their development and at the moment of formation of reproductive organs. Tree plants - after transplantation of seedlings and saplings, when the root system is injured. The same applies to vegetable and ornamental seedlings. Humates are used at all stages of plant development, starting with the seed soaking. Further treatment with humates is carried out during the vegetation period. At the same time, the consumption of humate is largely determined by the nature of the plant. For example, when growing grain plants (wheat, rye, oats, barley, etc.), it is necessary to introduce $2-5 \mathrm{~kg} / \mathrm{ha}$; technical crops (cotton, flax, etc.) $-4-6 \mathrm{~kg} / \mathrm{ha}$.

Presently, Tver State Technical University has the scientific bases for the development of technologies that increase agronomic and biological value of peat raw materials through the production of soil ameliorants [16]. It should be noted that ameliorant of soil is not fertilizer in the traditional sense. It is a complex (organic matrix + nutrients + humates + microelements), natural and environmentally friendly product. Ameliorant does not quantitatively (for example, as fertilizer, which increases the concentration of nutrients), but qualitatively improves the agrophysical, agrochemical, microbiological, biochemical, physical and chemical properties of the soil. Ameliorant in the form of granules (Figure 1) has a relatively high bulk density - 450-550 kg/m3, allowing for economically viable longdistance transportation. The size (diameter) of granules is 4-6 $\mathrm{mm}$ (change depending on application conditions is possible); water holding capacity on the average from 3 to $6 \mathrm{~kg}$ of water per $\mathrm{kg}$ of dry matter; the content of humic substances from 20 to $40 \%$, acidity $\mathrm{pH}=$ $3,5-6,5$.

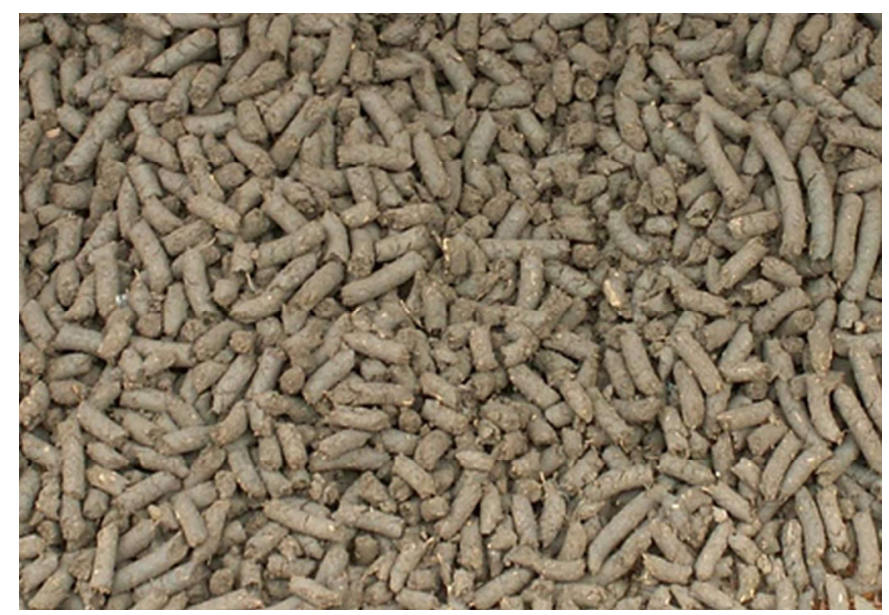

Fig 1. Peat humus ameliorant formed by extrusion method.

In terms of its agrochemical characteristics, humus peat ameliorant outperforms the most widely known types of organic fertilizers (Table 1). When mixed with local nonproductive soil in certain proportions, it reproduces and provides the functions of black soil, stimulates rapid acclimation, growth and development of any plants $[17,18]$. 
Table 1. Main characteristics of organic fertilizers.

\begin{tabular}{|c|c|c|c|c|c|}
\hline \multirow{3}{*}{ Fertilizer } & \multirow{3}{*}{$\begin{array}{c}\text { Humidity, } \\
\%\end{array}$} & \multicolumn{4}{|c|}{ Nutrients content, $\%$ of dry mass } \\
\hline & & \multicolumn{2}{|c|}{ Nitrogen } & \multirow{2}{*}{$\mathbf{P}_{2} \mathrm{O}_{5}$} & \multirow{2}{*}{$\mathbf{K}_{2} \mathbf{O}$} \\
\hline & & total & active forms & & \\
\hline Manure: & \multirow[b]{2}{*}{$75-80$} & \multirow[b]{2}{*}{0.6} & \multirow[b]{2}{*}{0.15} & \multirow[b]{2}{*}{$0.2-0.4$} & \multirow[b]{2}{*}{$0.5-0.6$} \\
\hline On straw bedding & & & & & \\
\hline On peat bedding & $75-80$ & 0.6 & 0.18 & $0.2-0.3$ & $0.5-0.6$ \\
\hline Compost: & \multirow{2}{*}{$60-75$} & \multirow{2}{*}{$2-3.5$} & \multirow{2}{*}{$0.06-0.5$} & \multirow{2}{*}{$0.2-0.4$} & \multirow{2}{*}{$0.4-1.2$} \\
\hline peat-manure & & & & & \\
\hline peat-liquid manure & $65-80$ & $2-3.5$ & $0.12-0.7$ & $0.15-0.4$ & $1.5-3$ \\
\hline peat-lime & $55-75$ & $2.3-3.2$ & $0.06-0.5$ & $0.01-0.08$ & 0.2 \\
\hline $\begin{array}{l}\text { Peat-ammonia } \\
\text { fertilizers: }\end{array}$ & \multirow[b]{2}{*}{$55-63$} & \multirow[b]{2}{*}{$1.3-3.5$} & \multirow[b]{2}{*}{0.5} & \multirow[b]{2}{*}{0.6} & \multirow[b]{2}{*}{0.6} \\
\hline Concentration \#1 & & & & & \\
\hline Concentration \#2 & $55-63$ & $1.6-3.8$ & 0.8 & 0.9 & 0.9 \\
\hline Humus peat ameliorant & $<30$ & 3.7 & 0.4 & 0.8 & 0.8 \\
\hline
\end{tabular}

Humus peat ameliorant can be used for any soil and in different climatic zones for growing most crops.

The developed structural scheme of ameliorants production is characterized by flexibility of technological process. It makes it possible to promptly change the composition and quantity of ingredients to be introduced depending on the customer's requirements, as well as to factor in the soil type and its initial state. The ecosystem created with the help of soil ameliorant is self-sufficient and self-developing. When strictly applied, the process of ecosystem development leads to the full restoration of once lost natural soil fertility.

One of the basic know-how of the developed technological scheme is the method of activation of peat humus. Thanks to it, the quantity of humic acids extracted from peat increases by 2-3 times compared to the currently used methods. It is important that the efficiency of ameliorant is determined to a certain extent by the method of its granulation (pelletizing, extrusion, rolling, etc.).

Application of modern highly effective humus ameliorants based on peat will not only help to improve the quality and quantity of agricultural products in Russian regions and abroad, but also to actively combat desertification of lands. This is especially relevant for areas with sandy and stony deserts (Africa, Middle East, Mongolia, China, etc.). In addition, ameliorants have a significant potential for application in restoration of anthropogenic disturbed lands: sandy substrates, artificial mounds, dumps of quarries, road slopes, ravines, eroded and contaminated soils.

It can be relatively easily applied manually, as well as using organic fertilizer spreaders and other equipment. To create a 15-centimeter fertile layer, it is necessary to spread up to $3 \mathrm{~kg}$ of ameliorant granules on $1 \mathrm{~m}^{2}$ of the surface evenly every five years and plow them into the soil with a shovel or cultivator (Figure 2). After this, abundant watering of the organo-sand mixture is performed. To achieve a quick effect in relatively small areas, it is recommended to pre-soak the granules in water and mix sand with wet granules. The resulting solution of humates is advisable to use for watering the mixture. Then, an aqueous solution of humates will come out in this layer, and mineral particles will be wetted by it. When water evaporates, a protective layer of dry humates will form on the soil surface and perform several functions. Firstly, it is a structure-forming layer that holds together sand particles, thereby reducing losses from wind erosion. Secondly, it reduces the intensity of evaporation from the surface of the fertile layer. And thirdly, it is a plant growth stimulator. The particles of ameliorant remaining in the soil layer will gradually decompose and form an organic basis for the formation of humus. In addition, they provide a prolonged yield of 
nutrients and a favorable air-water regime in the root layer. All subsequent agricultural activities are carried out using the traditional rules for cultivating the crop.

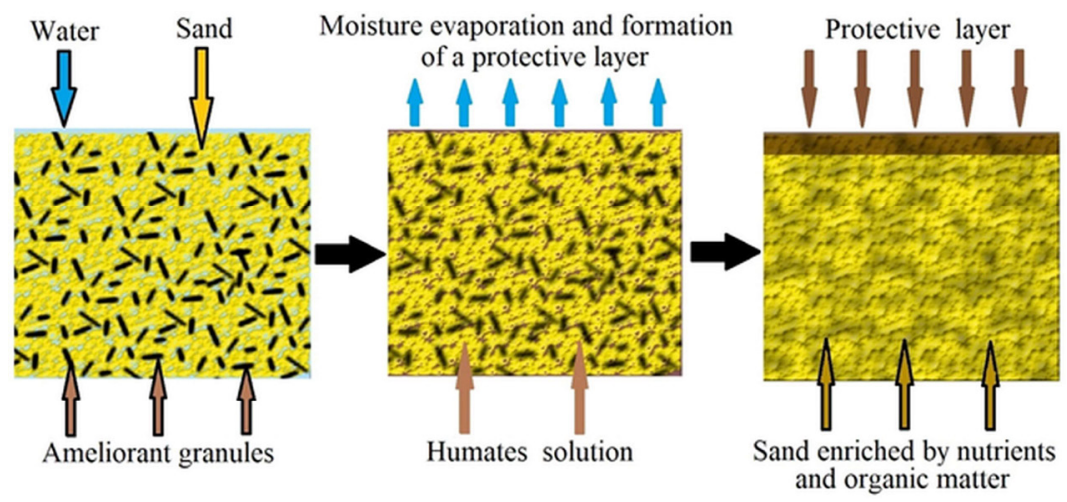

Fig. 2. Scheme of the proposed principle of using peat humus ameliorant.

The effectiveness of peat ameliorant has been experimentally proven for growing potatoes in the field. The experiments were carried out in the innovation center "Agrotechnical training ground" as part of the Tver State Agricultural Academy. Potatoes of the Nevsky variety were planted in sod-podzolic sandy loam soil using traditional technology. Tillage - autumn plowing, spring cultivation, tuber cutting, hilling. Ammophos was used as a mineral fertilizer. It was introduced based on $150 \mathrm{~kg} / \mathrm{ha}$ of the active substance of nitrogen, phosphorus and potassium $\left(\mathrm{N}_{150} \mathrm{P}_{150} \mathrm{~K}_{150}\right)$.

It was experimentally established that the use of the humus ameliorant provides a significant yield increase of potatoes (Table 2). Plant productivity increases from 57 to $72 \%$. No adverse side effects from the used granular ameliorant in plants were observed. Moreover, mineral fertilizers in studied doses were significantly less effective than the ameliorant.

Table 2. Dependence of the yield of potatoes on the type of fertilizer applied.

\begin{tabular}{|l|c|c|}
\hline \multicolumn{1}{|c|}{ Experiment option } & Yield, t/ha & $\begin{array}{c}\text { Increase to the control } \\
\text { group, } \%\end{array}$ \\
\hline Without fertilizer (control group) & 13.06 & - \\
\hline $\mathrm{N}_{150} \mathrm{P}_{150} \mathrm{~K}_{150}$ & 19.14 & 47 \\
\hline Ameliorant $(3 \mathrm{t} / \mathrm{ha})$ & 20.55 & 57 \\
\hline Ameliorant $(3 \mathrm{t} / \mathrm{ha})+\mathrm{N}_{150} \mathrm{P}_{150} \mathrm{~K}_{150}$ & 21.62 & 66 \\
\hline Ameliorant $(4 \mathrm{t} / \mathrm{ha})$ & 22.41 & 72 \\
\hline
\end{tabular}

The use of peat ameliorant helps to avoid negative effects resulting from lack of moisture in sandy soil. Water saving can be up to $50 \%$, which can at least double the intervals between irrigations. Due to its high water absorption capacity, ameliorant prevents irrigation water from entering the soil and reduces evaporation from its surface. At the same time, the content of large amounts of organic and mineral substances in the humus ameliorant makes it possible to reduce the number of watering plants to once a week. In some cases, it can reduce water consumption by 5-10 times.

\section{Conclusion}

Thus, the insufficient amounts of organic fertilizers must be compensated for by applying peat-based fertilizers to the soil. The use of peat the humus ameliorants will significantly reduce the need for irrigation water, and in some cases, eliminate (or significantly reduce) 
the use of traditional chemical, mineral and organic fertilizers. Different types of degraded lands under the influence of ameliorant components will independently turn into fertile soil suitable not only for planting and growing of different plant species (different types of recultivation works), but also for their subsequent agricultural application.

The large-scale production in many regions (especially the non-chernozem zone) of organic fertilizers and ameliorants based on peat for the needs of agricultural enterprises can become a real incentive for the development of peat business and, as a result, a powerful impulse for the socio-economic development of rural depressed areas.

\section{References}

1. L. Litvin, Z. Kiryukhina, S. Krasnov, N. Dobrovol'skaya, Eurasian Soil Science, 50:11, 1344-1353 (2017)

2. M. Rady, W. Semida, K. Hemida, M. Abdelhamid, International Journal of Recycling of Organic Waste in Agriculture, 5:4, 311-321 (2016)

3. A. Brondi, J. Daniel, V. Castro, A. Bertoli, J. Garcia, M. Trevisan, Communications in Soil Science and Plant Analysis, 47:22, 2506-2513 (2016)

4. B. Kogut, M. Yashin, V. Semenov, T. Avdeeva, L. Markina, S. Lukin, S. Tarasov, Eurasian Soil Science, 49:1, 45-55 (2016)

5. K Woli, J. Pantoja, J. Sawyer, Communications in Soil Science and Plant, 47:22, 25582572 (2016)

6. L. Mueller, G. Shepherd, U. Schindler, B. Ball, L. Munkholm, V. Hennings, E. Smolentseva, O. Rukhovic, Soil and Tillage Research, 127, 74-84 (2013)

7. M. Rajaie, A. Tavakoly, International Journal of Recycling of Organic Waste in Agriculture, 5:4, 339-347 (2016),

8. I. Lishtvan, Y. Yanuta, A. Abramets, V. Strigutskii, Y. Navosha, Solid Fuel Chemistry, 47:3, 147-152 (2013)

9. I. Lishtvan, V. Mulyarchik, A. Tomson, B. Kurzo, G. Naumova, N. Zhmakova, T. Tsaryuk, T. Sokolova, N. Makarova, T. Ovchinnikova, N. Sosnovskaya, V. Pekhtereva, L. Kalilets, Solid Fuel Chemistry, 51:5, 286-295 (2017)

10. E. Kremcheev, D. Nagornov, Ecology, Environment and Conservation, 23:2, 956-965 (2017)

11. E. Kremcheev, D. Nagornov, Life Science Journal, 11:11, 453-456 (2014)

12. M. Willich, A. Schiborra, L. Quaranta, A. Buerkert, Journal of Agriculture and Rural Development in the Tropics and Subtropics, 117:2, 323-333 (2016)

13. D. Baldantoni, L. Morra, G. Saviello, A. Alfani, Environmental Science and Pollution Research, 23:24, 25169-25179 (2016)

14. O. Misnikov, E3S Web of Conferences, 21, 01020 (2017)

15. O. Misnikov, A. Timofeev, O. Pukhova, Polymer Science. Series D, 8:1, 66-74 (2015)

16. A. Kosolapova, V. Yamaltdinova, E. Mitrofanova, D. Fomin, I. Teterlev, Bulgarian Journal of Agricultural Science, 22:6, 921-926 (2016)

17. E. Kremcheev, D. Nagornov, D. Kremcheeva, Lecture Notes in Earth System Sciences, 233-256 (2020)

18. N. Gamayunov, S. Gamayunov, Eurasian Soil Science, 38:3, 297-304 (2005) 